\title{
Educational Model for Overcoming Stunting Toddlers with Bio Acupressure Massage Using Pure Coconut Oil
}

\author{
Nyoman Ribek $^{1 *}$, I Gusti Ketut Gede Ngurah ${ }^{2}$, Ketut Labir ${ }^{3}$, Ketut Wardani ${ }^{4}$ (iD \\ 1,2,3,4 Health Polytechnic of the Ministry of Health Denpasar, Indonesia \\ *Corresponding author: nyomanribek0606@gmail.com
}

\begin{abstract}
Educational models to overcome stunting are needed because stunting has a negative impact on the health and function of the body as well as increasing child morbidity. The prevalence of stunting under five in Indonesia in 2019 was $27.67 \%$, in Bali $21.9 \%$ and Karangasem $26.23 \%$ above WHO 20\%. This data is the reason for conducting research in 2020. The aim is to find out whether the educational model of bio acupressure massage using virgin coconut oil can increase appetite, sleep quality and immune power so that stunting toddlers increase height. The research method is quasi-experimental; the research design is nonequivalent control group design. The sample is 50 people with purposive sampling technique. The analysis before and after treatment was carried out by paired sample t-test, the results were that all variables had significant differences ( $\mathrm{P}$ value $>0.05$ ). Variable differences between groups using t-two independent test with an alpha of 0.05 resulted in a significant difference in appetite $(\mathrm{P}$ value $=0.01)$ and a significant difference in height $(\mathrm{p}$ value $=0.020)$. There was no significant difference between sleep quality and endurance $(\mathrm{P}$ value $>0.05)$. It was concluded that there was a significant difference before and after education on stunting, while between the bio acupressure and conventional groups there was a significant difference in the variables of appetite and height. It is recommended that in overcoming stunting, bio acupressure massage education is the right education.
\end{abstract}

Keywords: Stunting, Education, Bio Acupressure Massage

$\begin{array}{lll}\text { History: } & & \text { Publisher: Undiksha Press } \\ \text { Received } & \text { : April 20, } 2021 & \text { Licensed: This work is licensed under } \\ \text { Revised } & \text { : April 21, } 2021 & \text { a Creative Commons Attribution 3.0 License } \\ \text { Accepted } & \text { : June 20, 2021 } & \text { Co (C) O }\end{array}$

\section{INTRODUCTION}

The background of this research is because the problem of stunting has a negative impact on health, affects body function and increases child morbidity and is in the spotlight of WHO to be resolved immediately. WHO places Indonesia as the third country with the highest stunting prevalence rate in Asia, the figure reached 36.4 percent, but decreased by $30.8 \%$ in 2018 and became $27.67 \%$ in 2019 , which means a decrease of $3.13 \%$ (Hall et al., 2018; Mahmudiono et al., 2017). Stunting data in Bali in 2019 amounted to 21.9\%, still above the $20 \%$ WHO set. Data in Bali shows that 5 regencies have stunting rates that are still concerning, one of which is Karangasem Regency which reaches 26.23 percent (Budiastutik \& Nugraheni, 2018; Saputri \& Tumangger, 2019; Trihono et al., 2015). This data is the reason why the research site was conducted at the Rendang Health Center, Karangasem Regency.

Stunting is a condition of growth failure in children due to malnutrition and lack of quality sleep for a long time, so that body length or height has a z-score value of less than 2SD (Beal et al., 2018; De Onis et al., 2012; De Onis \& Branca, 2016; Leroy \& Frongillo, 2019). Many factors cause stunting of children under five, including a lack of exclusive breastfeeding history, lack of family income, lack of education on maternal where the stunting rate is still high (Headey et al., 2018; Prendergast \& Humphrey, 2014; Prentice et al., 2013). In this connection, the researchers designed a massage education model which is considered to be able to help overcome the problem of stunting, namely the bio-massage educational model. The educational model of bio-massage massage is an educational model 
of massage by emphasizing a certain point along with withdrawal between joints and regulating breath, so that electromagnetic waves can increase energy and facilitate the flow of nutrients in the body so that appetite, sleep quality and immune power increase thus accelerating growth (Chirande et al., 2015; Crookston et al., 2011; Tiwari et al., 2014). This is in line with the theory (endorphins) and the immune theory which explains that pressing on the surface of the body will stimulate the release of substances that can relieve pain and increase the body's resistance to disease (Fitri, 2018; Torlesse et al., 2016). This data is what differentiates it from other research he has done and no one has ever published it. This study aims to find out the effect of the bio-acupressure massage educational model using virgin coconut oil on appetite; the effect of the bio-acupressure massage educational model using virgin coconut oil on sleep quality; the effect of the bio-acupressure massage educational model using virgin coconut oil on the body's immune system; the effect of the educational model of bio-acupressure massage using virgin coconut oil on height in stunting toddlers aged 24-60 months.

\section{METHODS}

This research method is a quasi-experimental design with a non-equivalent control group design (Sugiyono, 2019). A sample of 50 people was taken using the Rao Purba formula with the inclusion criteria for stunting toddlers aged 24-60 months, living in the Rendang Health Center, Karangasem Regency, able to communicate, see, hear and exclusion criteria for stunting toddlers who have wounds on their backs and body irritations such as reddish skin. The location of the research was carried out in the area of the Rendang Public Health Center, Karangasem Regency with a population of 39,500 in August 2020 consisting of 19,950 males and 19,630 females, with a total of 10,798 families and a total of 2514 children under five, of this number there are 95 stunting children and those who meet the study sample are 50 people with the results shown in Table 1.

Table 1. Distribution of Respondents Frequency by Gender

\begin{tabular}{lccccccc}
\hline \multirow{2}{*}{ Variable } & \multicolumn{2}{c}{ Intervention Group } & \multicolumn{2}{c}{ Control Group } & \multicolumn{2}{c}{ Total } \\
\cline { 2 - 9 } & \multicolumn{2}{c}{$\mathbf{N}$} & $\mathbf{\%}$ & $\mathbf{N}$ & $\mathbf{\%}$ & $\mathbf{N}$ & $\boldsymbol{\%}$ \\
\hline Gender & & & & & & & \\
Man & 14 & 56 & 16 & 64 & 30 & 60 \\
Women & 11 & 44 & 9 & 36 & 20 & 40 \\
\hline
\end{tabular}

Based on Table 1, it shows that the sex of stunting children under five is $60 \%$ more than male and $40 \%$ female. The sampling technique was purposive sampling technique with a population of 95 stunting toddlers from 2514 toddlers. Data collection techniques were obtained directly from respondents with the help of their mothers using questionnaires, weight scales and a stature meter. Data analysis was performed by normality test using the Shapiro-Wilk test. with a significance level of $p>0.05$.and different test using independent sample t paired test at a significant level of 5\% $(\alpha=0.05)$. This study has received approval from the Health Research Ethics Committee of the Health Polytechnic of the Ministry of Health Denpasar 


\section{RESULTS AND DISCUSSION}

\section{Results}

Analysis of differences in appetite, sleep quality and immune power before and after the intervention of Bio acupressure massage in stunting infants using VCO between intervention groups and control groups shown in Table 2. Based on table 2, it shows that there is a significant difference in appetite in the intervention group before and after the biomassage massage treatment $(\mathrm{P}$ value $=0.000)$ with a difference in value of 6.24 . whereas in the control group there was a small difference in value difference of 3.36 before and after conventional massage $(\mathrm{P}$ value $=0.00)$. The sleep quality variable found that there was a difference before and after the bio-massage massage treatment, namely 3.68, while in the control group there was a smaller difference, namely $3.44(\mathrm{P}=0.00)$.In the body's immune power there is also a difference with a difference of 3.48, while in the control group the difference is smaller, namely 2.48. The differences in height and weight before and after the intervention Bio acupressure between intervention group and control group shown in Table 3.

Table 2. Differences between intervention group and control group

\begin{tabular}{|c|c|c|c|c|c|c|c|}
\hline Variable & Group & $\mathbf{N}$ & Mean & SD & $95 \% \mathrm{CI}$ & $\mathbf{t}$ & P Value \\
\hline \multirow[t]{8}{*}{ Appetite } & Interve & & & & & \multirow[t]{4}{*}{24,61} & \multirow[t]{4}{*}{0.00} \\
\hline & Before & 25 & 30.44 & 2,72 & $.6,76-$ & & \\
\hline & After & 25 & 36,68 & 2,69 & 5,71 & & \\
\hline & Difference & & 6,24 & 1,26 & & & \\
\hline & Control & & & & & \multirow[t]{4}{*}{10.82} & \multirow[t]{4}{*}{0.00} \\
\hline & Before & 25 & 30.72 & 3,15 & $4,0-2,7$ & & \\
\hline & After & 25 & 34,08 & 2.67 & & & \\
\hline & Difference & & 3.36 & 1,55 & & & \\
\hline \multirow[t]{8}{*}{ Sleep quality } & Interve & & & & & \multirow[t]{4}{*}{13.677} & \multirow[t]{4}{*}{0.00} \\
\hline & Before & 25 & 18.72 & 2,30 & $4.23-3,12$ & & \\
\hline & After & 25 & 22.40 & 1.82 & & & \\
\hline & Difference & & 3.68 & 0.26 & & & \\
\hline & Control & & & & & \multirow[t]{4}{*}{22,39} & \multirow[t]{4}{*}{0.00} \\
\hline & Before & 25 & 18,92 & 2,53 & $3.75-3.12$ & & \\
\hline & After & 25 & 22,36 & 2.27 & & & \\
\hline & Difference & & 3.44 & 0.76 & & & \\
\hline \multirow{8}{*}{$\begin{array}{l}\text { Immune } \\
\text { power }\end{array}$} & Interve & & & & & \multirow[t]{4}{*}{19.95} & \multirow{4}{*}{0.00} \\
\hline & Before & 25 & 18,76 & 2,66 & $3.83-3.12$ & & \\
\hline & After & 25 & 22,24 & 2.38 & & & \\
\hline & Difference & & 3,48 & 0.87 & & & \\
\hline & Control & & & & \multirow{4}{*}{$2.95-2,00$} & \multirow[t]{4}{*}{10.69} & \multirow[t]{4}{*}{0.00} \\
\hline & Before & 25 & 19,68 & 2,63 & & & \\
\hline & After & 25 & 22.16 & 2.49 & & & \\
\hline & Difference & & 2.48 & & & & \\
\hline
\end{tabular}


Table 3. Difference in height and weight before and after the intervention Bio acupressure massage for stunted infants using virgin coconut oil between groups

\begin{tabular}{llllllll}
\hline Variable & Group & N & Mean & SD & 95\% CI & t & P Value \\
\hline Height & Intervention & & & & & & \\
& Before & 25 & 92.04 & 4.945 & $12,66-14,08$ & 2.195 & 0.00 \\
& After & 25 & 94.60 & 4.941 & & & \\
& Difference & & 2.56 & 0.004 & & & \\
& Control & & & & & & \\
& Before & 25 & 90.68 & 6.45 & $11,64-13,09$ & 1.055 & 0.057 \\
& After & 25 & 92.04 & 4.94 & & & \\
Weight & Difference & & 1.36 & & & & \\
& Intervention & & & & & & \\
& Before & 25 & 13,37 & 1,69 & $0.42-.0 .49$ & 2.402 & 0.00 \\
& After & 25 & 13.79 & 1.69 & & & \\
& Difference & & 0.46 & 0.09 & & & \\
& Control & & & & & & \\
& Before & 25 & 12.40 & 1.80 & $0.37-0.28$ & 1.498 & 0.00 \\
& After & 25 & 12.74 & 1.73 & & & \\
\hline & Difference & & 0.33 & & & & \\
\hline
\end{tabular}

Based on Table 3, it shows that there is a significant difference in height in the intervention group $(\mathrm{P}$ value $=0.000)$ with a difference in value of 2.56 , whereas in the control group there was no significant difference with a difference of 1.36 before and after conventional massage $(\mathrm{P}$ value $=0.057)$. There was a difference in body weight before and after treatment, namely 0.46, while in the control group there was a smaller difference, namely $0.33(\mathrm{P}=0.00)$. Educational effects of bio acupressure massage using virgin coconut oil on height stunting between groups of toddlers shown in Table 4.

Table 4. Educational effects of bio acupressure massage using virgin coconut oil on height stunting between groups of toddlers

\begin{tabular}{llllllll}
\hline Variable & Group & N & Mean & SD & 95\% CI & T & P Value \\
\hline Height & Intervention & 25 & 94.60 & 4.94 & 1.16 & 2.938 & 0.02 \\
& Control & 25 & 90.68 & 6.45 & $6-67$ & & \\
& Difference & & 3.92 & 6.67 & & & \\
\hline
\end{tabular}

Based on table 4 , it shows that the value of $\mathrm{P}=0.02$, which means that $\mathrm{P}<0.05$, so that $\mathrm{HO}$ is rejected, it means that it can be concluded that there is a significant difference in height in the intervention group with the control group after the stunting toddler massage treatment with a difference in value of 3.92. The effects of massage using virgin coconut oil on appetite, sleep quality and body resistance in stunting toddlers between groups shown in Table 5. Based on table 5 the results of the analysis show: 1). Appetite value of $P=0.001$ which means $\mathrm{P}<0.05$ so that $\mathrm{H} 0$ is rejected, it means that it can be concluded that there is a significant difference in appetite in the intervention group with the control group after massage treatment for children under five with stunting with a difference in value of $2.60,2$ ). Sleep quality value $\mathrm{P}=0.946$, which means $\mathrm{P}>0.05$ so that $\mathrm{H} 0$ is accepted, it means that it can be concluded that there is no significant difference in the quality of sleep in the intervention group with the control group after the stunting toddler massage treatment with a difference in value of $3.18,3$ ). Body endurance value $\mathrm{P}=0.908$, which means $\mathrm{P}>0.05$ so that $\mathrm{HO}$ is accepted, it means that it can be concluded that there is no significant difference in 
endurance in the intervention group with the control group after massage treatment for stunting toddlers with a difference in value of 0.800 .

Table 5. Effects of massage using virgin coconut oil on appetite, sleep quality and body resistance in stunting toddlers between groups

\begin{tabular}{|c|c|c|c|c|c|c|c|}
\hline Variabel & Group & $\mathbf{N}$ & Mean & SD & $95 \% \mathrm{CI}$ & $\mathbf{T}$ & P Value \\
\hline \multirow[t]{3}{*}{ Appetite } & Interv & 25 & 36.68 & 2.60 & & \multirow{3}{*}{3.258} & \multirow[t]{3}{*}{0.001} \\
\hline & Control & 25 & 34.08 & 2.67 & .953 & & \\
\hline & Difference & & 2.600 & & & & \\
\hline \multirow{3}{*}{$\begin{array}{l}\text { Sleep } \\
\text { quality }\end{array}$} & Interv & 25 & 22.40 & 1.82 & & \multirow{3}{*}{0.63} & \multirow[t]{3}{*}{0.946} \\
\hline & Control & 25 & 22.36 & 2.27 & $\begin{array}{l}1.27 \\
1.25\end{array}$ & & \\
\hline & Difference & & 0.4 & 3.18 & 1.35 & & \\
\hline \multirow{3}{*}{$\begin{array}{l}\text { Body } \\
\text { endurance }\end{array}$} & Interv & 25 & 22.24 & 2.38 & & \multirow[t]{3}{*}{0.117} & \multirow[t]{3}{*}{0.908} \\
\hline & Control & 25 & 22.16 & 2.49 & 1.32 & & \\
\hline & Difference & & 0.800 & .0 .41 & & & \\
\hline
\end{tabular}

\section{Discussions}

The results of the data analysis for stunting toddlers showed that there were 95 stunted toddlers out of 2514 children, which means that the number of children under five with stunting in the working area of the Rendang Health Center was $3.78 \%$. which means that it is above the WHO provisions by $20 \%$. In the study, 50 people were taken as the study sample with an average age in the intervention group and the control group which was almost the same at around 46 months, the youngest was 26 months and the oldest was 60 months or 5 years and the majority were male. This data supports the theory that stunting can occur when the fetus is still in the womb and only appears when the child is two years old. Based on the residence of the stunting toddlers used as the research sample, the largest number of samples were in the Pempatan Village with 23 toddlers or $46 \%$ and Pesaban Village 6\%. This village is geographically positioned close to the mountains with the highest number of children under five compared to other villages and Pesaban village is the lowest position.

The results of the analysis of the appetite variable showed that there was a significant difference with $(\mathrm{P}$ value $=0.00)$. The appetite for stunting of children under five who was given a massage with the bio-acupressure model changed with the difference between the difference before and after the treatment of 6.24 so that initially the average appetite was 30.44 with the sufficient category changed to 36.8 with good category. The results of the analysis in the control group also had a significant difference $(\mathrm{P}$ value $=0.00)$ Appetite in the group of stunting toddlers who were given conventional massage changed with the difference between before and after treatment 3.36 so that initially the average appetite was 30.08 with the sufficient category changed to 34.08 in the good category. The results of the analysis of appetite in the intervention group and the control group showed a significant difference ( $P$ value $=0.00$ ) with a difference of 2.60. Changes in appetite in the group of toddlers who were given the intervention of massage with the bio-acupressure model, besides being statistically acceptable, it can also be accepted as complementary science which states that one of the massage models is acupressure, which is a massage method on acupuncture points on the human body without using needles. In increasing appetite, three locations are used, namely 3 locations for the legs (It is located in the back of the inner ankle and 4 fingers up from the inner ankle and 4 fingers below the kneecap on the outer edge of the shinbone) and 2 locations of the hands (It is located 3 fingers above the inner wrist, on the back of the hand at the highest point when the thumb and forefinger are brought together) as well as the location on the stomach, which is around the navel in a circular motion, on the ribs area and then gently pull it outwards. 
The results of the analysis of sleep quality variables showed that there was a significant difference with $(\mathrm{P}$ value $=0.00)$ sleep quality in the intervention group with the difference before and after treatment 3.68 so that initially the average sleep quality was 18.72 in the moderate category, changed to 22.40 in the good category. The results of the analysis in the control group also showed that there was a significant difference $(P$ value $=0.00)$ with the difference before and after treatment 3.44 so that initially the average sleep quality was 18.92 with the moderate category changing to 22.36 in the good category. The results of the sleep quality analysis in the intervention group with the control group were not significantly different $(\mathrm{P}$ value $=0.95)$ with a difference of 0.04 . In the absence of significant differences between the intervention and control groups, one of the indications is that conventional massage also has the effect of making better sleep quality. Changes in sleep quality in the group of toddlers who were given an acupressure massage intervention model, besides being statistically acceptable, it can also be accepted in complementary care science where in improving sleep quality three locations are used, namely location of the foot (The location is located on the instep of the foot in the hollow between the joints of the toe bones of the big toe and the toes of the two feet) and; locations of the hands (The location on the back of the hand at the highest point when the thumb and forefinger are brought together, the location on the curve of the inner wrist line, in line with the little finger and the location; fingers above the middle of the inner wrist); The location on the head is at the midpoint between the eyebrows.

The results of the analysis of body immune variables showed that there was a significant difference with $(\mathrm{P}$ value $=0.00)$ The body's immune power in the intervention group changed with a difference of 3.48 before and after treatment so that initially the average body immune power was 18.76 with a moderate category changing to 22.24 with a good category. The results of the analysis in the control group also showed that there was a significant difference with $(\mathrm{P}$ value $=0.00)$. The body's immune power in the control group changed with a difference of 2.48 before and after treatment so that initially the average body immune power was 19.68 with the moderate category changing to 22.16 in the good category. The results of the analysis of the body's immune power in the intervention group with the control group there was no significant difference $(\mathrm{P}$ value $=0.90)$ with a difference of 0.08. In the absence of significant differences between the intervention and control groups, one of the indications that conventional massage at the time of massage also affects organs that are indicated to increase the body's immune power. In increasing the body's immune power, two locations are used, namely 2 locations on the legs (the location is 4 fingers above the inner ankle and the location is 4 fingers below the kneecap) and 1 location of the chest (Located on the chest by pressing the thymus point using four fingers each on the right and left chest for 5 minutes) With this data, massage can increase the body's resistance to prevent recurrent disease.

Educational Effects of Massage on Appetite, Sleep Quality, Immune Power and Height in Stunting Toddlers. The results of the study found that 2 dependent variables experienced a significant effect with the independent sample t-test where Ho was rejected on the variables of appetite and height. In the appetite variable, the value of $\mathrm{P}=0.001$ with a difference of 2.60. In the height variable, the $\mathrm{P}$ value $=0.02$ with a difference of 3.92 . The variables of sleep quality and body resistance are significantly Ho accepted, so it can be concluded that bioenergy massage has no difference with conventional massage. In the sleep quality variable, the value of $\mathrm{P}=0.946$ with a difference of 3.18 , while the endurance variable has the value of $\mathrm{P}=0.908$ with a difference of 0.80 . Thus, it means that the educational model of bio acupressure massage has more effect on increasing appetite when compared to conventional massage, while there is no difference in sleep quality and body immunity. An increase in appetite means that more food can enter the body, appetite is the 
desire to get certain types of food that are useful to eat (Hsieh et al., 2004; Mehta et al., 2017). The sensation of hunger, apart from the desire to eat, is also influenced by environmental, cultural, and physiological settings in the brain, especially the hypothalamus (Carotenuto et al., 2013; Semba et al., 2008). Appetite is regulated peripherally by adipose tissue and the gastrointestinal system, which then transmits these signals to the hypothalamus. There is no significant difference between bio acupressure massage and conventional massage on sleep quality and body resistance in stunting toddlers, but both massages can significantly improve sleep quality (Aryastami \& Tarigan, 2017; Budiastutik \& Nugraheni, 2018; Rokx et al., 2018; Trihono et al., 2015). Changes in sleep quality with the action of the acupressure massage model with a difference of 3.68 will accelerate changes in height. About $75 \%$ of growth hormone is released when the child sleeps, the hormone is in charge of stimulating bone and tissue growth, and regulating the body's metabolism, including the brain.

Changes in endurance by a difference of 3.48 will accelerate changes in height. Immune system is the body's ability to ward off all types of germs and viruses that will enter the body. If the immune system is good, then the body will be healthy. Conversely, if the body's resistance decreases, the germs can easily enter so that the body gets sick easily and ultimately the growth in height and weight will also be hampered. The results of the analysis showed that there was a significant difference in height in the intervention group before and after the stunting infant massage treatment $(\mathrm{P}$ value $=0.000)$ with a difference of 2.56. while in the control group there was no significant difference with a difference of 1.36 before and after conventional massage $(\mathrm{P}$ value $=0.057$ ). There was a difference in body weight before and after treatment, namely 0.46 , while in the control group there was a smaller difference, namely $0.33(\mathrm{P}=0.00)$.

\section{CONCLUSION}

There was a significant difference in appetite in the intervention group before and after the treatment of stunting toddler bio acupressure massage education model with the difference in the average value after treatment being greater than in the pre-treatment group, while in the control group also found differences but with a smaller difference than the intervention group., as well as between the intervention group and the control group there is also a significant effect. There was a significant difference in sleep quality in the intervention group before and after the treatment of stunting toddler bio acupressure massage education model with the difference in the average value after treatment being greater than the group before treatment, while in the control group also found differences but with a difference smaller than the intervention group. However, between the intervention group and the control group, no significant effect was found. There was a significant difference in the body's immune power in the intervention group before and after the massage treatment of the bio acupressure massage education model for stunting toddlers with the difference in the average value after treatment being greater than in the group before treatment, while in the control group there were also differences but with a difference smaller than that in the control group. intervention group, but between the intervention group and the control group no significant effect was found. There was a significant difference in height in the intervention group before and after the treatment of stunting toddler bio acupressure massage education model with the difference in the average value after treatment being greater than the group before treatment, while in the control group also found differences but with a difference smaller than the intervention group. as well as between the intervention group and the control group there was also a significant effect. It is recommended to the district health office that the bio acupressure massage education model for stunting toddlers is used as an alternative program 
for health centers in overcoming stunting problems in addition to implementing other health programs.

\section{REFERENCES}

Aryastami, N. K., \& Tarigan, I. (2017). Kajian kebijakan dan penanggulangan masalah gizi stunting di Indonesia. Buletin Penelitian Kesehatan, 45(4), 233-240. https://pdfs.semanticscholar.org/d6c/667c6a575f369b4e22605547d1de22d16e48.pdf.

Beal, T., Tumilowicz, A., Sutrisna, A., Izwardy, D., \& Neufeld, L. M. (2018). A review of child stunting determinants in Indonesia. Maternal \& Child Nutrition, 14(4). https://doi.org/10.1111/mcn.12617.

Budiastutik, I., \& Nugraheni, S. A. (2018). Determinants of stunting in Indonesia: A review article. International Journal of Healtcare Research, 1(2), 43-49. https://core.ac.uk/download/pdf/267886697.pdf.

Carotenuto, M., Gallai, B., Parisi, L., Roccella, M., \& Esposito, M. (2013). Acupressure therapy for insomnia in adolescents: a polysomnographic study. Neuropsychiatric $\begin{array}{llll}\text { Disease } & \text { and Treatment, } & \end{array}$ https://www.ncbi.nlm.nih.gov/pmc/articles/PMC3559075/.

Chirande, L., Charwe, D., Mbwana, H., Victor, R., Kimboka, S., Issaka, A. I., \& Agho, K. E. (2015). Determinants of stunting and severe stunting among under-fives in Tanzania: evidence from the 2010 cross-sectional household survey. BMC Pediatrics, 15(1), 113. https://doi.org/10.1186/s12887-015-0482-9.

Crookston, B. T., Dearden, K. A., Alder, S. C., Porucznik, C. A., Stanford, J. B., Merrill, R. M., \& Penny, M. E. (2011). Impact of early and concurrent stunting on cognition. Maternal \& Child Nutrition, 7(4), 397-409. https://doi.org/10.1111/j.17408709.2010.00255.x.

De Onis, M., Blössner, M., \& Borghi, E. (2012). Prevalence and trends of stunting among pre-school children, 1990-2020. Public Health Nutrition, 15(1), 142-148. https://doi.org/10.1017/S1368980011001315.

De Onis, M., \& Branca, F. (2016). Childhood stunting: a global perspective. Maternal \& Child Nutrition, 12, 12-26. https://doi.org/10.1111/mcn.12231.

Fitri, L. (2018). Hubungan BBLR Dan Asi Ekslusif Dengan Kejadian Stunting Di Puskesmas Lima Puluh Pekanbaru. Jurnal Endurance: Kajian Ilmiah Problema Kesehatan, 3(1), 131-137. https://doi.org/10.22216/jen.v3i1.1767.

Hall, C., Bennett, C., Crookston, B., Dearden, K., Hasan, M., Linehan, M., \& West, J. (2018). Maternal knowledge of stunting in rural Indonesia. International Journal of Child Health and Nutrition, 7(4), 139-145. https://doi.org/10.6000/1929-4247.2018.07.04.2.

Headey, D., Hirvonen, K., \& Hoddinott, J. (2018). Animal sourced foods and child stunting. American Journal of Agricultural Economics, 100(5), 1302-1319. https://doi.org/10.1093/ajae/aay053.

Hsieh, L. L. C., Kuo, C. H., Yen, M. F., \& Chen, T. H. H. (2004). A randomized controlled clinical trial for low back pain treated by acupressure and physical therapy. Preventive Medicine, 39(1), 168-176. https://doi.org/10.1016/j.ypmed.2004.01.036.

Leroy, J. L., \& Frongillo, E. A. (2019). Perspective: what does stunting really mean? A critical review of the evidence. Advances in Nutrition, 10(2), 196-204. https://doi.org/10.1093/advances/nmy101.

Mahmudiono, T., Sumarmi, S., \& Rosenkranz, R. R. (2017). Household dietary diversity and child stunting in East Java, Indonesia. Asia Pacific Journal of Clinical Nutrition, 26(2), 317-325. https://doi.org/10.3316/ielapa.688058173877148.

Mehta, P., Dhapte, V., Kadam, S., \& Dhapte, V. (2017). Contemporary acupressure therapy: 
Adroit cure for painless recovery of therapeutic ailments. Journal of Traditional and Complementary Medicine, 7(2), 251-263. https://doi.org/10.1016/j.jtcme.2016.06.004.

Prendergast, A. J., \& Humphrey, J. H. (2014). The stunting syndrome in developing countries. Paediatrics and International Child Health, 34(4), 250-265. https://doi.org/10.1179/2046905514Y.0000000158.

Prentice, A. M., Ward, K. A., Goldberg, G. R., Jarjou, L. M., Moore, S. E., Fulford, A. J., \& Prentice, A. (2013). Critical windows for nutritional interventions against stunting. The American of Clinical Nutrition, 97(5), 911-918. https://doi.org/10.3945/ajen.112.052332.

Rokx, C., Subandoro, A., \& Gallagher, P. (2018). Aiming high: Indonesia's ambition to reduce stunting. World Bank.

Saputri, R. A., \& Tumangger, J. (2019). Hulu-hilir penanggulangan stunting di Indonesia. Journal of Political Issues, 1(1), 1-9. https://doi.org/10.33019/jpi.v1i1.2.

Semba, R. D., de Pee, S., Sun, K., Sari, M., Akhter, N., \& Bloem, M. W. (2008). Effect of parental formal education on risk of child stunting in Indonesia and Bangladesh: a cross-sectional study. The Lancet, 371, 322-328. https://doi.org/10.1016/S01406736(08)60169-5.

Sugiyono. (2019). Metode Penelitian Pendidikan. Alfabeta.

Tiwari, R., Ausman, L. M., \& Agho, K. E. (2014). Determinants of stunting and severe stunting among under-fives: evidence from the 2011 Nepal Demographic and Health Survey. BMC Pediatrics, 14(1), 1-15. https://doi.org/10.1186/1471-2431-14-239.

Torlesse, H., Cronin, A. A., Sebayang, S. K., \& Nandy, R. (2016). Determinants of stunting in Indonesian children: evidence from a cross-sectional survey indicate a prominent role for the water, sanitation and hygiene sector in stunting reduction. BMC Public Health, 16(1), 1-11. https://doi.org/10.1186/s12889-016-3339-8.

Trihono, T., Atmarita, A., Tjandrarini, D. H., Irawati, A., Nurlinawati, I., Utami, N. H., \& Tejayanti, T. (2015). Pendek (stunting) di Indonesia, masalah dan solusinya. Lembaga Penerbit Badan Litbangkes. 